\title{
Bioactive peptides in young animal nutrition
}

\author{
R. Zabielski \\ The Kielanowski Institute of Animal Physiology and Nutrition, \\ Polish Academy of Sciences \\ 05-110 Jabtonna. Poland
}

\begin{abstract}
Maternal milk contains a number of bioactive peptides and proteins important for the development of the gastrointestinal tract. This article briefly reviews information on milk insulin, insulinlike growth factors, and epidermal growth factor. Since recently leptin has been found in maternal milk, a more detailed overview of leptin's effects on gastrointestinal tract function is presented. The physiological importance of milk leptin needs, however, further investigation. In contrast to milk, artificial milk formulas contain markedly lower amounts of bioactive peptides.
\end{abstract}

KEY WORDS: EGF, IGF, insulin, leptin, colostrum, milk, ncwborn

\section{INTRODUCTION}

In modern animal production, increasing interest is being paid to animal physiology, but economics (a farmer's or company's profit) are usually a far more important matter. The domination of economy over the physiological needs of production animals can be observed from the first hours after birth. From the economic point of view, a shorter suckling period and feeding with either milk replacers or solid feed is better. In this case, economics means less human labour and more offspring delivered per year. From the economical point of view, it is also better to replace milk protein in the milk formula with other (read: cheaper) protein sources. Animal studies have shown, however, that the kind of feed (milk, milk replacer and weaned feed), its composition in regard to the presence of bioactive milk substances, and the mode of feeding (suckling vs bottle feeding) have a great impact on the development of the gastrointestinal tract, in particular on maturation of small intestinal mucosa, and overall animal performance. In many studies the importance of 
colostrum and milk bioactive peptides and proteins for sucklings have been emphasized. However, these natural substances are readily inactivated by milk processing, for instance the concentrations of insulin, leptin, EGF and IGF-1 in infant formulas based on bovine milk are low or undetectable (Read et al., 1985; Nagashima et al., 1990; Smith-Kirwin et al., 1998). The examined porcine milk formula contained only $4 \%$ of insulin and $1 \%$ of IGF as compared with sow colostrum (Biernat et al., 2001). No commercial milk formula is supplemented so far with the growth factors and hormones relevant for the development of the neonatal gastrointestinal tract. On the other hand, however, sucklings and weaners are offered feedstuff containing a wide range of feed additives, and again economics has decided about the use of these substances, e.g., $\mathrm{ZnO}$ and antimicrobial feed additives, despite the hazardous effects reported by microbiologists, medical and veterinary clinicians, and ecologists (Opaliński et al., 1998; Taljański-Zygmunt et al., 1998).

\section{DEFINITION OF BIOACTIVE PEPTIDES}

The term "bioactive peptides" is wide since it covers both the peptides derived from food proteins and the peptides naturally present in the food. According to Schlimme and Meisel (1995) bioactive peptides derived from food protein, are protein fragments that are inactive within the sequences of their precursors but interact with appropriate receptors and affect the physiological functions of an organism after being released by proteolytic enzymes (e.g., casomorphins derived from $\alpha$-and $\beta$-casein of milk). Table 1 shows some known bioactive peptides derived from milk protein and their biological activity. Since milk replacers and feed-

TABLE 1

Bioactive peptides derived from milk protein hydrolysates (Kostyra and Kostyra, 1992; Wong et al., 1996; Mcisel, 1997, 1998; Rudloff and Kunz, 1997; Schanbacher et al., 1997; Tirelli et al., 1997; Dziuba et al., 1999; Yamamoto and Takano, 1999)

\begin{tabular}{lll}
\hline Bioactive peptide & Protein precursor & Bioactivity \\
\hline Casomorphins & $\alpha$-, $\beta$-Casein & Opioid agonists \\
$\alpha$-Lactorphin & $\alpha$-Lactalbumin & Opioid agonist \\
$\beta$-Lactorphin & $\beta$-Lactoglobulin & Opioid agonist \\
Lactoferroxins & Lactoferrin & Opioid antagonists \\
Casoxins & k-Casein & Opioid antagonists \\
Casokinins & $\alpha$-, $\beta$-Casein & Angiotensin-I-converting-enzyme inhibitors \\
Immunopeptides & $\alpha$-, $\beta$-Casein & Immunomodulators \\
Lactoferricin & Lactoferrin & Antimicrobial agent \\
Casoplatelins & $\mathrm{k}$-Casein & Antithrombotic agents \\
Phosphopeptides & $\alpha-, \beta$-Casein & Mineral binding agents \\
$\beta$-Lactotensin & $\beta$-Lactoglobulin & Ileum smooth muscle contracting agent \\
\hline
\end{tabular}


stuffs for early weaners contain considerable amounts of milk proteins, these bioactive peptides may appear in sufficient amounts in the gastrointestinal tract. Plant and animal proteins in the diet (e.g., wheat gluten, rye albumin, soyabean conglycinins, haemoglobin, egg ovomucin) may deliver numerous bioactive peptides, often having similar activity to those derived from milk proteins.

In contrast, bioactive peptides naturally present in food are active components of the food (milk) that retain their biological activity in the lumen of the gastrointestinal tract. Table 2 lists the relevant bioactive peptides, hormones and growth

TABLE 2

Bioactive peptides occurring naturally in milk and colostrum (Rao, 1991; Koldovsky et al., 1995; Smith-Kirwin et al., 1998; Xu, 1998; Zabielski, 1998)

\begin{tabular}{ll}
\hline Hormones & $\begin{array}{l}\text { Insulin, somatostatin, thyroxin, calcitonin, prolactin, growth hormone, growth } \\
\text { releasing factor, oxytocin, melatonin, atrial natriuretic peptide, endothelin-1, } \\
\text { angiotensin I converting cnzyme, gastrin, leptin }\end{array}$ \\
\hline Growth factors & $\begin{array}{l}\text { EGF-I, -II (epidermal growth factor-I and -II), IGF (insulin-like growth } \\
\text { factor), NGF (nerve growth factor), TGF (transforming growth factor- } \alpha \text { and } \\
\text { - } \beta \text { ) PDGF (platelet-derived growth factor) }\end{array}$
\end{tabular}

factors naturally present in colostrum and milk. All of them have their endogenous counterparts secreted both systemically into the circulating blood and locally into the lumen of the gastrointestinal tract with saliva, gastric, intestinal, and pancreatic juices and bile (Rao, 1991). For example, saliva and enterocytes are important sources of growth factors (IGF, EGF); pancreatic juice contains remarkable amounts of insulin and gastric juice, leptin.

\section{ROLE OF BIOACTIVE PEPTIDES PRESENT IN MILK FOR THE SUCKLING}

The list of recognized colostrum and milk bioactive peptides and their biological effects is rapidly growing. These milk bioactive substances are particularly important during the first days of postnatal life for the development of the gastrointestinal tract as well as for induction of the neonate's own endocrine system. In the following pages I will briefly review only just a few of them, for more details please refer to a number of extensive reviews published in the last 15 years (Thornburg and Koldovsky, 1987; Koldovsky et al., 1988, 1995; Rao, 1991; Grosvenor et al., 1992; Schlimme and Meisel, 1995; Xu, 1996, 1998; Guimont et al., 1997; Rudloff and Kunz, 1997; Schanbacher et al., 1997; Tirelli et al., 1997; Zinn, 1997; Meisel, 1998; Zabielski, 1998; Yamamoto and Takano, 1999; Blum and Hammon, 2000; Xu et al., 2000). Following the recent discovery of leptin receptors in the 
gastrointestinal tract and high leptin concentrations in the colostrum and milk (Aoki et al., 1999; Ucar et al., 2000), a new question arose on the potential involvement of leptin in the development of the gastrointestinal tract.

Bioactive peptides are present in milk at concentrations usually much higher than those found in maternal blood or in the blood and tissues of their offspring. Weström et al. (1987) have reported that the concentration of insulin in sow colostrum is over 100 times greater than in maternal plasma and that it drops gradually during lactation. Blum and Hammon (2000) have demonstrated a similar pattern with regard to insulin, prolactin and IGF-I in bovine colostrum and milk. The reduction in milk glucagon and growth hormone was far less dramatic in their study. High concentrations of insulin and IGF-1 in colostrum and milk coincide with intensive growth of the intestinal mucosa and pancreas tissue just after birth (Svendsen et al., 1986). Colostrum and milk bioactive peptides seem to be particularly important in neonates to support their neuroendocrine function and regulate the development of GI tract structure and function until the neonate's own endocrine system achieves maturity. The degradation of bioactive peptides occurs to a much lower degree in the digestive juices of neonates and sucklings than in those of weaned or adult animals (Read et al., 1987; Shen and Xu, 1996; Xu et al., 1996). There are controversies on the ability to penetrate the gut tissue and appearance of milk bioactive peptides in the circulating blood. Thornburg and Koldovsky (1987), Rao (1991), Xu and Wang (1996), Shen and Xu (2000) have found the gut permeable to numerous milk hormones and growth factors (insulin, IGF-I), on the other hand Grütter and Blum (1991), Vacher et al. (1995), Donovan et al. (1997) and Hadorn et al. (1997), observed no absorption of insulin, prolactin and IGF-I from the gut lumen into the general circulation in newborns. The discrepancy among different reports may be due to different media used to deliver the bioactive peptides (colostrum vs milk formula) since Sangild et al. (1999) reported that colostrum promotes the intestinal absorption of macromolecules. However, according to the present view, the majority of biological effects of colostrum and milk peptides is rather limited to the gastrointestinal tract (Blum and Hammon, 2000; Xu et al., 2000).

\section{Insulin}

Colostrum and milk insulin may exert local as well as general effects, although according to experiments in neonatal calves by Grütter and Blum (1991) it seems not to be absorbed in the intestine. Insulin acts through its own receptors and through IGF type I receptors due to its approximately $40 \%$ homology with IGFs. Administration of pharmacological doses of insulin increased the weight of the small intestine, in particular that of intestinal mucosa, and increased lactase and maltase activities in neonatal piglets (Shulman, 1990). Feeding a neonate pig with colostrum 
devoid of insulin inhibits maturation of intestinal enzymes (Wang and $\mathrm{Xu}, 1996$ ) and delays gut closure, thus insulin is regarded as an important maturation factor of gastrointestinal tract mucosa. Oral administration of insulin causes hypoglycaemia in neonatal pigs and calves (Koldovsky et al., 1988).

\section{Insulin-like growth factor}

Peptide growth factors, such as IGF-I, IGF-II and EGF, are present in biologically relevant amounts in maternal milk from different species. These peptides are remarkably stable in rat and pig gastrointestinal fluids suggesting that after ingestion of milk they may reach their receptors in the mucosa of the stomach, duodenum and proximal jejunum in an active form (Shen and Xu, 1996; Fellah et al., 2001). In suckling piglets, IGF-I receptors are widely distributed in the small intestinal mucosa, and located in the apical part of the enterocyte (Morgan et al,, 1996). According to Donovan et al. (1997) and Hammon and Blum (1997), IGF-I is not absorbed in the small intestine in calves and pigs, even immediately after birth, though colostrum ingestion causes a marked increase of IGF-l in blood plasma (Egli and Blum, 1998). Feeding piglets with an infant formula supplemented with IGF-I and IGF-II leads to a higher DNA content in the stomach tissue and increases cell proliferation in the upper gut as compared with infant formula alone (Xu et al., 1994). In neonatal calves, orally administered recombinant human IGF-I stimulated growth of the intestine as evidenced by $\left[{ }^{3} \mathrm{H}\right]$-thymidine incorporation into the enterocyte (Baumrucker et al., 1994), but histological examination of the intestinal mucosa did not reveal any effect (Blum and Hammon, 2000). IGF-I can modulate the tight junction structures that are also associated with intestinal permeability, and enhance intestinal epithelial $\mathrm{Na}^{+}$and $\mathrm{Na}^{+}$-coupled nutrient absorption (Alexander and Carey, 1999). The importance of IGF-I in rat and human milk has been questioned by others since it was found that endogenous IGF-I may be produced in sufficient amounts in the newborn and taken up selectively by the proximal gut (Burrin, 1997; Steeb et al., 1997). However, experiments on calf neonates showed that plasma IGF-I concentrations depend on the amount and timing of colostrum ingestion (Blum and Hammon, 2000).

\section{Epidermal growth factor}

EGF is stable in gastric and duodenal fluids (Thornburg et al., 1984; Rao, 1991) and acts through specific receptors located on the epithelial cells along the oesophagus, stomach and small intestine (Jaeger and Lamar, 1992). In suckling pigs the density of EGF receptors is significantly lower than in weaned pigs (Kelly et al., 1992). After ingestion, EGF stimulates epithelial cell growth and differentiation (James et al., 1987; Thornburg and Koldovsky, 1987), increases the specific acti- 
vity of mucosal omithine decarboxylase and incorporation of labeled thymidine into DNA (Ulshen et al., 1986; Berseth, 1987), and elevates jejunal lactase- and sucrase-specific activities (Jaegger et al., 1990). EGF is reported to be involved in the cessation of macromolecular transmission in newborn (Xu et al,, 2000), and plays an important role in the maintenance of epithelial integrity, inhibition of intestinal bacteria translocation (Okuyama et al., 1998), as well as in the gastric and intestinal epithelium recovery after rotavirus and bacterial infections (Zijlstra et al., 1994; Buret et al., 1998).

\section{Leptin in colostrum and milk}

Leptin, a 16-kDa cytokine secreted primarily by adipose tissues, has recently been shown to be produced by the human placenta (Smith-Kirwin et al., 1998). Many functions of the placenta are replaced by the mammary gland in terms of providing critical growth factors for the newborn. Consequently, leptin is produced by the mammary epithelial cells and it has been detected in human, mice, and rat colostrum and milk (Casabiell et al., 1997; Houseknecht et al., 1997; Aoki et al., 1999; Ucar et al., 2000). Leptin is present in whole breast milk at 30- to 150 -fold higher concentrations than in skim milk (Houseknecht et al., 1997; Smith-Kirwin et al., 1998). In the breast milk, leptin was found in higher (Smith-Kirwin et al., 1998), similar (Houseknecht et al., 1997) or lower (Ucar et al., 2000) concentrations than present in the maternal plasma, nevertheless, milk leptin concentrations positively correlated with maternal and/or infant plasma leptin concentrations. In other examined species, the concentration of leptin in milk was higher than in the maternal blood plasma. In lactating mice the leptin concentration of milk collected just before weaning was about two-fold higher than that of the milk collected at mid-lactating stages (Aoki et al., 1999). In experimental animals, Casabiell et al. (1997) have demonstrated that leptin is transferred from the circulation to mothers' milk, then to the infant's stomach and afterwards to the infant's blood.

\section{Leptin function in the juvenile gut}

According to Lin et al. (2000), in $50 \mathrm{~d}$-old pig foetuses the long form leptin receptor mRNA is expressed in the brain, intestine, liver and umbilical cord, and in $105 \mathrm{~d}$-old gilts it is expressed in the intestine, liver and pancreas. In the juvenile rat, leptin receptor expression has been found in several tissues including small intestine (Lostao et al., 1998). In mice, expression of the functional isoform leptin receptor is restricted to the jejunum and is readily detected in isolated enterocytes from this site by the RT-PCR technique (Morton et al., 1998), suggesting that the epithelium of the jejunum is a direct target of leptin action. Indeed, Lostao et al. (1998) have originally demonstrated that leptin has a rapid inhibitory effect on 
sugar absorption in the rat intestinal mucosa in vitro. In their study, leptin inhibited D-galactose uptake by rat small intestinal rings, respectively by 33 and $56 \%$ after 5 and $30 \mathrm{~min}$ of incubation! However, neither at $5 \mathrm{~min}$ nor at $30 \mathrm{~min}$ did leptin prevent intracellular galactose accumulation. These results show for the first time that leptin may exert its "antiobesity" effects locally in the small intestine. Recently, Yuan et al. (2000) evaluated the effects of peripherally administered leptin on body weight changes in neonatal rats during the early suckling period (from birth to $10 \mathrm{~d})$. Daily i.p. injections of leptin $(0.3$ and $1.0 \mu \mathrm{g} / \mathrm{g})$ to neonatal rats led to a significant reduction in weight gain over $10 \mathrm{~d}$ compared with the control group. In addition, they also observed that $3 \mathrm{~d}$ after discontinuing leptin treatment, the body weight of leptin-treated pups returned to the control level. In a recent study in neonatal piglets that were fed for 6 days with either pig milk formula alone or formula supplemented with pharmacological doses of leptin, Woliński et al. (2001) have found that in the leptin- supplemented group the weight of the stomach was significantly reduced and that of the pancreas, increased. Moreover, in isolated muscle strips in vitro they have found that the neonates supplemented with leptin had a significantly higher amplitude of spontaneous and acetylocholine-induced contractions in the duodenum than the non-supplemented neonates. In contrast, muscle strips taken from the mid-jejunum showed opposite results (Woliński et al., 2001). The mechanism of leptin action remains obscure. Yuan et al. (1999) have demonstrated in neonatal rat in vitro preparations that the peripheral gastric application of leptin modulates brain stem neuronal activities via afferent sensory fibres (Yuan et al., 1999). In adult rats, exogenous leptin or that released endogenously by CCK or meal is accompanied by a significant rise in gastric blood flow probably mediated by NO and sensory nerves (Brzozowski et al., 1999). Data accumulated so far suggest that colostrum and milk leptin may play a role in the regulation of gastrointestinal tract function in neonates, but further studies are necessary.

\section{FUTURE PERSPECTIVES}

Bioactive peptides need to be recognized as a novel measure of protein value in addition to the essential amino acid content criterion (Friedman, 1996), and the criteria based on protein allergenicity and presence of antinutrients occurring together with proteins (Anantharaman and Finot, 1993; Matsuda and Nakamura, 1993; Bush and Hefle, 1996). This criterion should be used in particular for evaluation of artificial milk formulas, and liquid and solid feedstuffs for early weaned production animals. Research on colostrum and milk bioactive peptides, involving leptin, and their physiological role in the offspring is warranted.

Future research should be directed toward improving milk conservation technologies and the biological quality of milk replacers and feedstuffs for early weaned 
production animals. Looking for better quality means: 1. protection of biological activity of native milk proteins and peptides, in particular those that are present in milk in active form, 2 . supplementation of milk formula with native bioactive peptides, and 3. supplementation with selected bioactive peptides isolated from plants or obtained by biotechnological techniques. For example, spermine (Dufour et al., 1988) and kidney bean lectin (Biernat et al., 2001a) have been reported to stimulate the maturation of the gastrointestinal tract in sucklings, thus giving a chance for reduction of weaning problems.

\section{REFERENCES}

Alexander A.N., Carey H.V., 1999. Oral IGF-I enhances nutrient and electrolyte absorption in neonatal piglet intestine. Amer. J. Physiol. 277, G619-GG625

Anantharaman K., Finot P.A., 1993. Nutritional aspects of food proteins in relation to technology. Food Rev. Int. 9, 629-655

Aoki N., Kawamura M., Matsuda T., 1999. Lactation-dependent down regulation of leptin production in mouse mammary gland. BBA - Gen. Subjects 1427, 298-306

Baumrucker C.R., Hadsell D.L., Blum J.W., 1994. Effects of dietary insulin-like growth factor I on growth and insulin-like growth factor receptors in neonatal calf intestine. J. Anim. Sci. 72, 428433

Berseth L., 1987. Enhancement of intestinal growth in neonatal rats by epidermal growth factor in milk. Amer. J. Physiol. 253, G662-G665

Biernat M., Gacsalyi U., Radberg K., Zabielski R., Weström B., Pierzynowski S.G., 2001a. Effect of kidney bean lectin on gut morphology - a way to accelerate mucosa development. In: J.E. Lindberg, B. Ogle (Editors). Proceedings of the $8^{\text {th }}$ Digestive Physiology in Pigs Symposium. CABI, Wallingford, pp. 46-48

Biernat M., Zabielski R., Yao G., Marion J., le Huërou-Luron I., le Dividich J., 2001b. Effect of formula vs. sow's milk feeding on the gut morphology in neonatal piglets. In: J.E. Lindberg, B. Ogle (Editors). Proceedings of the $8^{\text {th }}$ Digestive Physiology in Pigs Symposium. CABI, Wallingford, pp. 43-45

Blum J.W., Hammon H., 2000. Colostrum effects on the gastrointestinal tract, and on nutritional, endocrine and metabolic parameters in neonatal calves. Livest. Prod. Sci. 66, 151-159

Bush R.K., Hefle S.L., 1996. Food allergens. Crit. Rev. Food Sci. Nutr. 36, S119-S163

Buret A., Olson M.E., Gall D.G., Hardin J.A., 1998. Effects of orally administered epidermal growth factor on enteropathogenic Escherichia coli infection in rabbits. Infect. Immunity 66, 4917 4923

Burrin D.G., 1997. Is milk-borne insulin-like growth factor-I essential for neonatal development? J. Nutr. 127, 975S-979S

Brzozowski T., Konturek P.C., Konturek S.J., Pajdo R., Duda A., Pierzchalski P., Biclanski W., Hahn E.G., 1999. Leptin in gastroprotection induced by cholccystokinin or by a meal. Role of vagal and sensory nerves and nitric oxide. Eur. J. Pharmacol. 374, 263-76

Casabiell X., Pineiro V., Tome M.A., Peino R., Dieguez C., Casanueva F.F., 1997. Presence of leptin in colostrum and/or breast milk from lactating mothers: a potential role in the regulation of neonatal food intake. J. Clin. Endocrinol. Metab. 82, 4270-4273 
Dufour C., Dandrifosse G., Forget P., Vermesse F., Romain N., Lepoint P., 1988. Spermine and spermidine induce intestinal maturation in the rat. Gastroenterology 95, 112-116

Donovan S.M., Chao J.C.J., Zijlstra R.T., Odle J., 1997. Orally administered iodinated recombinant human insulin-like growth factor-I is poorly absorbed by the newborn piglet. J. Pediat. Gastroenterol. Nutr. 24, 174-182

Dziuba J., Minkiewicz P., Nałęcz D., 1999. Biologically active peptides from plant and animal proteins. Pol. J. Food Nutr. Sci. 49, 3-16

Egli C.P., Blum J.W., 1998. Clinical, haematological, metabolic and endocrine traits during the first three months of life of suckling Simmentaler calves held in a cow-calf operation. J. Vet. Med. A $45,99-118$

Fellah A.M., Philipps A.F., Gillespie T.J., Galo J.R., Dvořák B., 2001. Degradation of insulin-like growth factors in small intestine of suckling rats. Regul. Peptides 98, 19-25

Friedman M., 1996. Nutritional value of proteins from different food sources. A review. J. Agr. Food Chem. 44, 6-29

Grosvenor C.E., Picciano M.F., Baumrucker C.R., 1992. Hormones and growth factors in milk. Endocrine Rev. 14, 710-728

Grütter R., Blum J.W., 1991. Insulin and glucose in neonatal calves after peroral insulin and intravenous glucose administration. Reprod. Nutr. Develop. 31, 389-397

Guimont C., Marchall E., Girardet J.M., Linden G., 1997. Biologically active factors in bovine milk and dairy byproducts: influence on cell culture. Crit. Rev. Food Sci. Nutr. 37, 393-410

Hadorn U., Hammon H., Bruckmaier R., Blum J.W., 1997. Delaying colostrum intake by one day has important effects on metabolic traits and on gastrointestinal and metabolic hormones in neonatal calves. J. Nutr. 127, 2011-2023

Hammon H., Blum J.W., 1997. The somatotropic axis in neonatal calves can be modulated by nutrition, growth hormone and Long-R -IGF-I. Amer. J. Physiol. 273, E130-E138

Houseknecht K.L., McGuire M.K., Portocarrero C.P., McGuire M.A., Beerman K., 1997. Leptin is present in human milk and is related to maternal plasma leptin concentration and adiposity. Biochem. Biophys. Res. Commun. 240, 742-747

Jaeger L.A., Lamar C.H., 1992. Immunolocalization of epidermal- growth factor (EGF) and EGF receptors in the porcine upper gastrointestinal tract. Amer. J. Vet. Res. 53, 1685-1692

Jaeger L.A., Lamar C.H., Cline T.R., Cardona C.J., 1990. Effect of orally administered epidermal growth factor on the jejunal mucosa of weaned pigs. Amer. J. Vet Res. 51, 471-474

James P.S., Smith M.W., Tivey D.R., Wilson T.J.G., 1987. Epidermal growth factor selectively increases maltase and sucrase activities in neonatal piglet intestine. J. Physiol. 393, 583-594

Kelly D., McFadyen M., King T.P., Morgan P.J., 1992. Characterization and autoradiographic localization of the epidermal growth factor receptor in the jejunum of neonatal and weaned pigs. Reprod. Fertil. Develop. 4, 183-191

Koldovsky O., Bedrick A., Pollack P., Rao R.K., Thornburg W., 1988. Biology of human milk: possible physiological role of hormones and hormone related substances present in milk. Nestle Nutrition Workshop Ser., Vol 15. L.A. Hanson (Editor). Nestle Ltd., Vevey/Raven Press, Ltd., New York, pp. 123

Koldovsky O., Illnerova H., Macho L., Strbak V., Stepankova R., 1995. Milk-borne hormones: possible tools of communication between mother and suckling. Physiol. Res. 44, 349-35I

Kostyra H., Kostyra E., 1992. Biologically active peptides derived from food proteins. Pol. J. Food Nutr. Sci. 42, 5-17

Lin J., Barb C.R., Matteri R.L., Kraeling R.R., Chen X., Meinersmann R.J., Rampacek G.B., 2000. Long form leptin receptor $m R N A$ expression in the brain, pituitary, and other tissues in the pig. Domest. Anim. Endocrinol. 19, 53-61 
Lostao M.P., Urdaneta E., Martinez-Anso E., Barber A., Martinez J.A., 1998. Presence of leptin receptors in rat small intestine and leptin effect on sugar absorption. FEBS Lett. 423, 302-306

Matsuda T., Nakamura R., 1993. Molecular structure and immunological properties of food allergens. Trends Food Sci. Technol. 4, 289-293

Meisel H., 1997. Biochemical properties of bioactive peptides derived from milk proteins: potential nutraceuticals for food and pharmaceutical applications. Livest. Prod. Sci. 50, 125-138

Meisel H., 1998. Overview on milk protein-derived peptides. Int. Dairy J. 8, 363-373

Morgan C.J., Coutts A.G.P., McFadyen M.C., King T.P., Kelly D., 1996. Characterization of IGF-I receptors in the porcine small intestine during postnatal development. J. Nutr. Biochem. 7, 339-347

Morton N.M., Emilsson V., Liu Y.L., Cawthorne M.A., 1998. Leptin action in intestinal cells. J. Biol. Chem. 273, 26194-26201

Nagashima K., Itoh K., Kuroume T., 1990. Levels of insulin-like growth factor I in full- and preterm human milk in comparison to levels in cow's milk and in milk formulas. Biol. Neonate $58,343-346$

Okuyama H., Urao M., Drongowski R.A., Coran A.G., 1998. The effect of epidermal growth factor on bacterial translocation in newborn rabbits. J. Pediat. Surg. 33, 225-228

Opaliński K.W., Dmowska E., Makulec G., Mierzejewska E., Petrov P., Pierzynowski S. G., Wojewoda D., 1998. The reverse of the medal: feed additives in the enviroment. J. Anim. Feed Sci. 7 , Suppl. 1, 35-44

Rao R.K., 1991. Biologically active peptides in the gastrointestinal lumen. Life Sci. 48, 1685-1704

Read L.C., Gale S.M., George-Nascimento C., 1987. Intestinal absorption of epidermal growth factor in newborn lambs. In: A.S. Goldman, S.A. Atkinson, L.A. Hanson (Editors). Human Lactation. 3. The Effects of Human Milk on the Recipient Infant. Plenum Press, New York, pp. 199-204

Read L.C., Upton F.M., Francis G.L., Wallace J.C., Dahlenberg G.W., Ballard F.J., 1985. Growth factor concentrations and growth-promoting activity of human milk following premature birth. J. Develop. Physiol. 7, 135-145

Rudloff S., Kunz C., 1997. Protein and nonprotein nitrogen components in human milk, bovine milk, and infant formula: quantitative and qualitative aspects in infant nutrition. J. Pediat. Gastroenterol. Nutr. 24, 328-344

Sangild P.T., Trahair J.F., Loftager M.K., Fowden A.L., 1999. Intestinal macromolecule absorption in the fetal pig after infusion of colostrum in utero. Pediat. Res. 45, 595-602

Schanbacher F.L., Talhouk R.S,. Murray F.A., 1997. Biology and origin of bioactive peptides in milk. Livest. Prod. Sci. 50, 105-123

Schlimme E., Meisel H., 1995. Bioactive peptides derived from milk proteins. Structural, physiological and analytical aspects. Nahrung 39, 1-20

Shen W.H., Xu R-J., 1996. Stability of epidermal growth factor in the gastrointestinal lumen of suckling and weaned pigs. Life Sci. 59, 197-208

Shen W.H., Xu R.J., 2000. Gastrointestinal stability and absorption of insulin in suckling pigs. Comp. Biochem. Physiol. Pt. A 125, 389-401

Shulman R.J., 1990. Oral insulin increases small intestinal mass and disaccharidase activity in the newborn miniature pig. Pediat. Res. 28, 171-175

Smith-Kirwin S.M., O'Connor D.M., De Johnston J., Lancey E.D., Hassink S.G., Funanage V.L., 1998. Leptin expression in human mammary epithelial cells and breast milk. J. Clin. Endocrinol. Metab. 83, 1810-1813

Steeb C.B., Shoubridge C.A., Tivey D.R., Read L.C., 1997. Systemic infusion of IGF-I or LR3IGF-I stimulates visceral organ growth and proliferation of gut tissues in suckling rats. Amer. J. Physiol. 272, G522-G533. 
Svendsen L.S., Weström B.R., Svendsen J., Ohlsson B.G., Ekman R., Karlsson B.W., 1986. Insulin involvement in intestinal macromolecular transmission and closure in neonatal pigs. J. Pediat. Gastroenterol. Nutr. 5, 299-304

Taljański-Zygmunt W., Grzesiuk E., Zabielski R., Pierzynowski S.G., 1998. Is the use of microbial drugs in agriculture risky for human health? J. Anim. Feed Sci. 7, Suppl. 1, 289-295

Thornburg W., Koldovsky O., 1987. Growth factors in milk: their effect on the developing gastrointestinal tract. In: N. Kretchmer, E.J. Qilligan, J.D. Johnson (Editors). Prenatal and Perinatal Biology and Medicine. Vol 1. Physiology and Growth. Harwood Academic Publisher, Chru (Switzerland), pp. 161-177

Thornburg W., Matrisian L., Magun B., Koldovsky O., 1984. Gastrointestinal absorption of epidermal growth factor in suckling rats. Amer. J. Physiol. 246, G80-G85

Tirelli A., DeNoni I., Resmini P., 1997. Bioactive peptides in milk products. Ital. J. Food. Sci. 9, 91-98

Ucar B., Kirel B., Bor O., Kilic F.S., Dogruel N., Aydogdu S.D., Tekin N., 2000. Breast milk leptin concentrations in initial and terminal milk samples: relationships to maternal and infant plasma leptin concentrations, adiposity, serum glucose, insulin, lipid and lipoprotein levels. J. Pediatr. Endocrinol. Metab. 13, 149-56

Ulshen M.H., Lyn-Cook L.E., Raash R., 1986. Effects of intraluminal epidermal growth factor on mucosal proliferation in the small intestine of adult rats. Gastroenterology $91,1134-1140$

Wang T., Xu R-J., 1996. Effect of colostrum feeding on intestinal development in newborn pigs. Biol. Neonate 70, 339-348

Weström B.R., Ekman R., Svendsen L., Svendsen J., Karlsson B.W., 1987. Levels of immunoreactive insulin, neurotensin, and bombesin in porcine colostrum and milk. J. Pediat. Gastroenterol. Nutr, 6, 460-465

Woliński J., Leśniewska V., Biernat M., Bąbelewska M., Korczyński W., Zabielski R., 2001. Exogenous leptin influences gastrointestinal growth and in vitro small intestinal motility in neonatal piglets - preliminary results. J. Anim. Feed Sci. 10, Suppl. 2, 249-254

Wong D.W.S., Camirand W.M., Pavlath A.E., 1996. Structures and functionalities of milk proteins. Crit. Rev. Food Sci. Nutr. 36, 807-844

Xu R.-J., 1996. Development of the newborn Gl tract and its relation to colostrum/milk intake: a Review. Reprod. Fertil. Develop. 8, 35-48

Xu R-J., 1998. Bioactive peptides in milk and their biological and health implications. Food Rev. Int. $14,1-16$

Xu R.-J., Mao Y.L., Tso M.Y.W., 1996. Stability of gastrin in the gastrointestinal lumen of suckling, weanling and adult pigs. Biol. Neonate 70, 60-68

Xu R.-J., Mellor D.J., Birtles M.J., Brier B.H., Gluckman P.D., 1994. Effects of oral IGF-I or IGF-II on digestive organ growth in newborn piglets. Biol. Neonate 66, 280-287

Xu R.J., Wang T., 1996. Gastrointestinal absorption of insulin-like growth factor-I in neonatal pigs. J. Pediat. Gastroenterol. Nutr. 23, 430-437

Xu R.-J., Wang F., Zhang S.H., 2000. Postnatal adaptation of the gastrointestinal tract in neonatal pigs: a possible role of milk-borne growth factors. Livest. Prod. Sci. 66, 95-107

Vacher P.-Y., Bestetti G., Blum J.W., 1995. Insulin-like growth factor I absorption in the jejunum of neonatal calves. Biol. Neonate 68, 354-367

Yamamoto N., Takano T., 1999. Antihypertensive peptides derived from milk proteins. Nahrung 43, 159-164

Yuan C.S., Attele A.S., Wu J.A., Zhang L., Shi Z.Q., 1999. Peripheral gastric leptin modulates brain stem neuronal activity in neonates. Amer. J. Physiol. 277, G626-G630

Yuan C.S., Attcle A.S., Zhang L., Lynch J.P., Xie J.T., Shi Z.Q., 2000. Leptin reduces body weight gain in neonatal rats. J. Pediat. Res. 48, 380-383 
Zabielski R., 1998. Regulatory peptides in milk, food, and in the gastrointestinal lumen of young animals and children. J. Anim. Feed Sci. 7, Suppl. 1, 65-78

Zijlstra R.T., Odle J., Hall W.F., Petschow B.W., Gelberg H.B., 1994. Effect of orally administered epidermal growth factor on intestinal recovery of neonatal pigs infected with rotavirus. J. Pediat. Gastroenterol. Nutr. 19, 382-390

Zinn S.A., 1997. Bioactive components in milk: introduction. Livest. Prod. Sci. 50, 101-103

\section{STRESZCZENIE}

\section{Bioaktywne peptydy w żywieniu mlodych zwierząt}

Mleko matki jest dla noworodka źródłem wielu bioaktywnych peptydów potrzebnych dla harmonijnego rozwoju przewodu pokarmowego. Artykuł jest krótkim przeglądem badań nad rolą pełnioną przez insulinę, insulinopodobne czynniki wzrostowe i nablonkowy czynnik wzrostu mleka u noworodków i osesków. Leptyna w mleku została odkryta niedawno, dlatego stosunkowo więcej miejsca poświęcono na zaprezentowanie wyników badań nad rolą leptyny w rozwoju przewodu pokarmowego. Jednakże określenie fizjologicznego znaczenia tych wyników wymaga dalszych badan. Preparaty mlekozastępcze, w przeciwieństwie do mleka, zawierają znikome ilości bioaktywnych peptydów. 